\title{
One-step Easy-Care and Softening Finishing of Knitted Cotton Fabric
}

\author{
Umut Kıvanç Şahin $^{1}$, Elçin Emekdar² ${ }^{*}$, Hatice Açıkgöz-Tufan ${ }^{3}$, Durul Büşra Dilden ${ }^{4}$, Muhammed Fatih Yüksel ${ }^{5}$ \\ 1 İTÜ, Tekstil Teknolojileri ve Tasarımı Fakültesi, Tekstil Mühendisliği Bölümü, İstanbul, Türkiye, (ORCID: 0000-0003-3074-3633), sahinumut@,itu.edu.tr \\ ${ }^{2 *}$ íTÜ, Tekstil Teknolojileri ve Tasarımı Fakültesi, Tekstil Mühendisliği Bölümü, İstanbul, Türkiye, (ORCID: 0000-0001-9964-0099), emekdar@itu.edu.tr \\ 3 İTÜ, Tekstil Teknolojileri ve Tasarımı Fakültesi, Tekstil Mühendisliği Bölümü, İstanbul, Türkiye, (ORCID: 0000-0002-7825-4372), acikgozh@itu.edu.tr \\ ${ }^{4}$ Eren Perakende Ar-Ge Merkezi, Çorlu, Türkiye (ORCID: 0000-0002-4636-7698), durulbusra.dilden@erenperakende.com \\ ${ }^{5}$ Eren Perakende Ar-Ge Merkezi, Çorlu, Türkiye (ORCID: 0000-0003-4239-3212), fatih.yuksel@erenperakende.com
}

(International Conference on Design, Research and Development (RDCONF) 2021 - 15-18 December 2021)

(DOI: 10.31590/ejosat.1041052)

ATIF/REFERENCE: Şahin, U.K., Emekdar, E., Açıkgöz-Tufan, H., Dilden, D.B. \& Yüksel, M.F. (2021). One-step Easy-Care and Softening Finishing of Knitted Cotton Fabric. European Journal of Science and Technology, (32), 1199-1202.

\begin{abstract}
Cotton is a natural fiber which has a tendency to wrinkle due to its perfect absorbancy properties. Nowadays, people prefer to use easycare fabrics, so a lot of research has been done about this issue since the 1940s. In most researches, carboxymethylation and causticization processes are applied to bleached or semi-bleached cotton fabric, yet in this project dyed cotton fabric is used. Factories are applying resin finishing which is expensive, decreases fabric strength, increases stiffness of fabric so handle affected poorly from this application. Formaldehyde-based chemistries were used for increase wrinkle recovery performance of fabrics before, but formaldehyde is a suspicious carcinogenic chemical very dangerous for human health. Currently, DMDHEU and BTCA are the most well-known crosslinking chemical materials in wrinkle-free finishing, but in this study, cationic silicone softener was used as the crosslinker, and its effect on crease resistance was investigated. In the study, after the dyed cotton fabrics were given anionic character by applying causticization with Sodium Hydroxide $(\mathrm{NaOH})$ and carboxymethylation processes with Sodium Chloroacetate (SCA), respectively, three different concentrations of cationic silicone were applied with the pad-dry-cure method for the cross-linking process. Then, wrinkle recovery angle (WRA) measurements were performed on crosslinked cotton fabrics in order to understand the interaction between causticization and crosslinking; and determine the better causticization and crosslinking levels that offer highest fabric performance. Experimental results showed that the best WRA results were observed at $10 \% \mathrm{NaOH}, 0.5 \mathrm{M}$ SCA. Same SCA and softener concentration with $15 \% \mathrm{NaOH}$ has adverse effect compared to $5 \%$ and $10 \% \mathrm{NaOH}$ levels.
\end{abstract}

Keywords: Cotton, Colored Fabric, Carboxymethylation, Ionic Croslinking, SCA, Cationic Silicone.

\section{Örme Pamuklu Kumaşlar için Tek Adımda Kolay Bakım ve Yumuşatma Bitim İşlemi}

$\ddot{O} \mathbf{z}$

Pamuk, mükemmel emici özellikleri nedeniyle kırışmaya meyilli doğal bir elyaftır. Günümüzde insanlar bakımı kolay kumaşları kullanmayı tercih etmektedir bu nedenle 1940'lardan bu yana bu konuda birçok araştırma yapıllmıştır. Çoğu araştırmada ağartılmış veya yarı ağartılmış pamuklu kumaşlara karboksimetilasyon ve kostikleştirme işlemleri uygulanmıştır ancak bu projede boyalı pamuklu kumaş kullanılmaktadır. Fabrikalar, pahalı olan, kumaş mukavemetini azaltan, kumaşın sertliğini artıran reçine terbiyesi uygulamaktadır, bu nedenle bu uygulamadan tuşe olumsuz etkilenmektedir. İnsan sağllğı için çok tehlikeli kanserojen bir kimyasal olan formaldehit daha önce kumaş buruşmasını azaltmak için kullanılmaktaydı. Günümüzde DMDHEU ve BTCA, buruşmazlık apresinde en iyi bilinen çapraz bağlayıcı kimyasal maddelerdir, ancak bu çalışmada, iyonik çapraz bağlı katyonik silikonun kırışma direnci üzerindeki etkisi araştırılmıştır. Çalışmada, boyanmış pamuklu kumaşlara sırasıyla kostiklerme ve karboksimetilasyon işlemleri uygulanarak anyonik karakter kazandırıldıktan sonra çapraz bağlama aşaması için pad-dry-cure yöntemi ile üç farklı konsantrasyonda katyonik silikon uygulanmıştır. Daha sonra kostikleme ve çapraz bağlama arasındaki ilişkinin anlaşılması ve en yüksek kumaş performansını sunan kosikleme ve çapraz bağlama seviyeleriin tespit edilmesi için boyalı pamuklu kumaşlarda kırışmazlık açısı (WRA)

\footnotetext{
*Sorumlu Yazar: emekdar@itu.edu.tr
} 
ölçümleri yapılmıştır. Deneysel sonuçlara göre en iyi WRA sonuçları \%10 NaOH, 0.5M SCA'da gözlenmiştir. \%15 NaOH ile aynı SCA ve yumuşatıcı konsantrasyonu $\% 5$ ve $\% 10 \mathrm{NaOH}$ seviyelerine kıyasla olumsuz etkiye sahiptir.

Anahtar Kelimeler: Pamuk, Renkli Kumaş, Karboksimetilasyon, İyonik Çapraz Bağlama, SCA, Katyonik Silikon.

\section{Introduction}

Today, studies have focused on making the finishing processes of cotton fabrics environmentally friendly and development of sustainable chemicals that provide maximum benefit, as well as making the application processes of these finishes high quality and innovative, which consumes less water and energy. In the last 50 years, the demand for $100 \%$ cotton clothes and "easy-care" products has increased gradually, with the comfort features of fabrics used in daily life coming to the fore. In this context, chemical finishes that cause formaldehyde release on fabric surfaces during the application phase, such as dimethylol dihydroxyethylene urea (DMeDHEU), dihydroxy dimethyl imidazolidinone (DHDMI), are conventionally used to provide a permanent ironing feature, at the same time, in order to provide an easy-care feature to the clothes. In this way, the wrinkle recovery of cotton fabrics increases. However, the negative and carcinogenic effects of formaldehyde threaten both the environment and operator health to a great extent. The use of anti-crease finishes containing formaldehyde is restricted and prohibited in many industrialized countries (Hashem, Refaie, \& Hebeish, 2005; Şahin, Gürsoy, Hauser, \& Smith, 2011).

There is a need for an anti-wrinkle treatment that uses more accessible, more cost-effective chemicals compared to commercially available ones, and does not adversely affect the properties of the fabric, as well as does not release formaldehyde. The ionic crosslinking process is a good alternative that has the potential to meet these requirements. Since the chemical structure obtained as a result of this process is completely different from the chemical structure obtained as a result of permanent-press, cotton fabric does not cause formaldehyde release. Ionic crosslinking is a two-step process applied on cotton fabric. The first step focuses on making cotton anionic via carboxymethylation. As a result of this process, there is an increase in the properties of the material such as moisture gain, dirt repellency, breaking strength, and elongation at break. The second step achieves ionic crosslinking of carboxymethylated cotton with a polycationic chemical (Şahin, Gürsoy, Hauser, \& Smith, 2011).

Bilgen (2005), in his study, treated cotton fabric with chloroacetic acid (CAA) that gives cotton an anionic character, and crosslinked the anionic cotton with many polycations including cationized chitosan, cationized glycerin, and cationized ethylene glycol. Cotton was also reacted with cationic materials, e.g., 3-chloro-2-hydroxypropyl trimethyl ammonium chloride (CHTAC) that gave it cationic character, and then with a polyanion such as 1,2,3,4-butanetetracarboxylic for ioniccrosslinking. As a result, it was observed that higher performances in fabric crease recovery were obtained for the treatment of anionic cellulosic fabrics with various polycations (Bilgen, 2006).

Resin finishing is widely used to impart high wrinkle recovery and improve handle properties of niche knitted products. However, the process comprises application of expensive resin as well as auxiliary chemicals. In this study, it is aimed to eliminate the need for resin finishing step by increasing the wrinkle resistance of dyed cotton fabrics with pique construction with a low cost and environmentally friendly method, improving the touch and fabric handle properties. When dyed cotton fabric becomes anionic, its affinity for cationic chemicals will increase compared to untreated dyed cotton fabric. Then, with the cationic silicone application to the fabric, the fabric will gain a very soft touch. With carboxymethylation and cross-linking processes, the rubbing, light fastness, and color fastness of the fabrics to washing will also be improved.

\section{Material and Method}

\subsection{Fabric}

Scoured, bleached, and dyed pique cotton fabric supplied from Eren Perakende ve Tekstil A.Ş. was used in this study. The fabric unit weight was $180 \mathrm{~g} / \mathrm{m}^{2}$.

\subsection{Chemicals}

Chemicals used for causticization included sodium hydroxide supplied from Fluka Chemical Company, sodium carbonate supplied from TEKKIM Company, and monochloroacetic acid supplied from Akkim Company. Chemicals used for ionic crosslinking included cationic modified silicone provided by Eren Perakende ve Tekstil A.Ş. and acetic acid supplied from Merck used in the neutralization of the silicon solution.

In causticization process, cellulosic fibers were treated with caustic soda solution which consists of sodium hydroxide and Grade 3 water, and pad-dry method was used. Cotton fabrics were treated with three different $\mathrm{NaOH}$ solutions. Fabrics were soaked in selected $\mathrm{NaOH}$ solution for 10 minutes, followed by padding to $100 \%$ wet pick-up of, and drying in oven at $70{ }^{\circ} \mathrm{C}$ for 10 minutes. After that, the fabrics were left to dry at room temperature.

Following causticization, fabrics were treated with sodium chloroacetate. Sodium chloroacetate was prepared prior to carboxymethylation. Demanded amount of monochloroacetic acid was dissolved in water, followed by neutralization with sodium carbonate. Pad-dry-pad-batch method was used for this process. Fabrics soaked in prepared solutions for 5 minutes, then padded to $100 \%$ wet pick-up. The wet fabrics were placed in polyethylene bag and tightly closed. They were dried in the oven for 1 hour at $70^{\circ} \mathrm{C}$. Respectively fabrics were dipped to distilled water for 5 minutes, rinsed under tap water for 5 minutes and dipped to Grade 3 water for a further 5 minutes. Then fabrics were left to dry at room temperature.

All carboxymethylated fabrics were soaked in one of the three different cationic silicone solutions with 1:30 liquor ratio. The reaction $\mathrm{pH}$ was reached with addition of demanded amount of acetic acid. After that, fabrics were treated in Gyrowash Washing Machine separately at $50{ }^{\circ} \mathrm{C}$ for 35 minutes. They were than dried in the oven at $100{ }^{\circ} \mathrm{C}$ for 5 minutes, and cured at 170 ${ }^{\circ} \mathrm{C}$ for 3 minutes. Prior to testing, fabrics were conditioned according to ISO139 for 24 hours before testing.

All independent variables (design factors) and their applied levels were presented in Table 1. A full-factorial experimental setup was constructed and applied. 


\subsection{WRA}

TS 390 EN 22313 /April 1996 Standards and SDL Atlas Crease Recovery Tester and Loading Device was used in this test. The fabrics were first compressed under $1 \mathrm{~kg}$ of weight for 5 minutes and then placed in the crease recovery tester, and the first measurement value was reported as First WRA $\left(^{\circ}\right)$. The second measurement was made after 5 minutes and reported as Final WRA $\left(^{\circ}\right)$.

Table 1. Experimental Design

\begin{tabular}{c|c}
\hline Parameters & Levels \\
\hline Causticization $(\% \mathrm{NaOH}, w / w)$ & $5,10,15$ \\
\hline Carboxymethylation $(\mathrm{M}, \mathrm{SCA})$ & $0.5,1,1.5,2$ \\
\hline Ionic Crosslinking $(\%$ Cationic Silicone, $w / w)$ & $1,2,3$ \\
\hline
\end{tabular}

\section{Results and Discussion}

The WRA results were presented in Table 2. It is apparent from data on Table 2 that the best WRA results were achieved at $10 \% \mathrm{NaOH}, 0.5 \mathrm{M}$ SCA. Same SCA and Softener concentration with $15 \% \mathrm{NaOH}$ has adverse effect compared to $5 \%$ and $10 \%$ $\mathrm{NaOH}$ levels. It is observed that high $\mathrm{NaOH}$ concentration applied on cotton fabric increases the rigidity of the fabric, causing increase in stiffness and thus a poor wrinkle recovery performance.

Effect of softener percentage on WRA is presented in Figure 1. It is apparent from data presented in Figure 1 that WRA decreased with increasing softener concentration, especially at higher carboxymethylation levels. It is concluded that the high chemical load results in lower final amounts of crosslinks due to interaction and complex formation of oppositely-charged macromolecules.

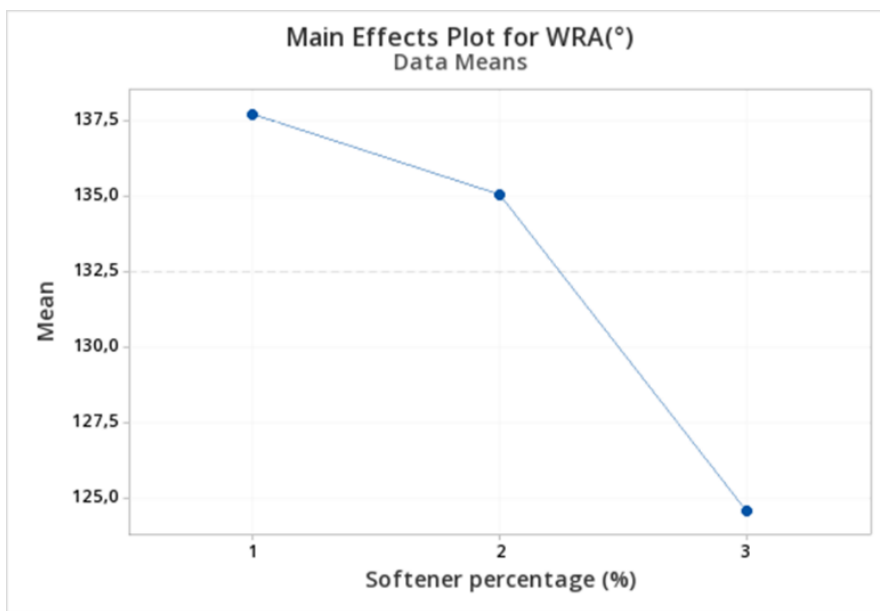

Figure 1. Effect of softener percentage (\%) on WRA $\left(^{\circ}\right)$.

\section{Conclusions and Recommendations}

While the bursting strength of the fabrics decreases as a result of the conventional method, the bursting strength of the fabrics increases when the ionic crosslinking method is used. For the practical applications of the performed work, no additional machine cost or chemical purchase is required to the traditional production lines. Causticizing and ionic crosslinking processes increase the light and washing fastness of fabrics. The fact that there is no need for additional equipment, the chemicals used are environmentally friendly, the fabric strength is not adversely affected, high wrinkle recovery, good color fastness and improved touch show that it will be advantageous to implement this project in the industrial field.

\section{Acknowledge}

The authors would like to thank R\&D Center of Eren Perakende ve Tekstil A.Ş. for their support throughout the study. Results presented here are part of preliminary studies as part of the project (Project ID: AGM 29) conducted under R\&D Center of Eren Perakende ve Tekstil A.Ş.. The authors also would like to thank Bilge Melikoğlu and Ecenaz Duygun for their support in production and testing stages of the study. 
Table 2. WRA Test Results of Ionic Crosslinked Fabrics

\begin{tabular}{|c|c|c|c|c|}
\hline $\begin{array}{l}\text { Causticization } \\
(\% \mathrm{NaOH}, \mathrm{w} / \mathrm{w})\end{array}$ & $\begin{array}{c}\text { Carboxymethylation } \\
\text { (M, SCA) }\end{array}$ & $\begin{array}{c}\text { Ionic Crosslinking } \\
(\% \text { Cationic } \\
\text { Silicone, w/w) } \\
\end{array}$ & $\begin{array}{c}\text { First } \\
\text { WRA } \\
\left({ }^{\circ}\right) \\
\end{array}$ & $\begin{array}{c}\text { Final WRA } \\
\left({ }^{\circ}\right)\end{array}$ \\
\hline $5 \%$ & $0.5 \mathrm{M}$ & 1 & 128 & 142 \\
\hline $5 \%$ & $0.5 \mathrm{M}$ & 2 & 162 & 177 \\
\hline $5 \%$ & $0.5 \mathrm{M}$ & 3 & 142 & 165 \\
\hline $5 \%$ & $1 \mathrm{M}$ & 1 & 133 & 143 \\
\hline $5 \%$ & $1 \mathrm{M}$ & 2 & 95 & 93 \\
\hline $5 \%$ & $1 \mathrm{M}$ & 3 & 83 & 86 \\
\hline $5 \%$ & $1.5 \mathrm{M}$ & 1 & 153 & 172 \\
\hline $5 \%$ & $1.5 \mathrm{M}$ & 2 & 147 & 152 \\
\hline $5 \%$ & $1.5 \mathrm{M}$ & 3 & 86 & 88 \\
\hline $5 \%$ & $2 \mathrm{M}$ & 1 & 62 & 61 \\
\hline $5 \%$ & $2 \mathrm{M}$ & 2 & 70 & 72 \\
\hline $5 \%$ & $2 \mathrm{M}$ & 3 & 159 & 169 \\
\hline $10 \%$ & $0.5 \mathrm{M}$ & 1 & 144 & 150 \\
\hline $10 \%$ & $0.5 \mathrm{M}$ & 2 & 167 & 176 \\
\hline $10 \%$ & $0.5 \mathrm{M}$ & 3 & 164 & 177 \\
\hline $10 \%$ & $1 \mathrm{M}$ & 1 & 126 & 136 \\
\hline $10 \%$ & $1 \mathrm{M}$ & 2 & 113 & 130 \\
\hline $10 \%$ & $1 \mathrm{M}$ & 3 & 145 & 160 \\
\hline $10 \%$ & $1.5 \mathrm{M}$ & 1 & 125 & 133 \\
\hline $10 \%$ & $1.5 \mathrm{M}$ & 2 & 144 & 159 \\
\hline $10 \%$ & $1.5 \mathrm{M}$ & 3 & 73 & 63 \\
\hline $10 \%$ & $2 \mathrm{M}$ & 1 & 116 & 136 \\
\hline $10 \%$ & $2 \mathrm{M}$ & 2 & 115 & 130 \\
\hline $10 \%$ & $2 \mathrm{M}$ & 3 & 135 & 154 \\
\hline $15 \%$ & $0.5 \mathrm{M}$ & 1 & 126 & 142 \\
\hline $15 \%$ & $0.5 \mathrm{M}$ & 2 & 116 & 131 \\
\hline $15 \%$ & $0.5 \mathrm{M}$ & 3 & 126 & 140 \\
\hline $15 \%$ & $1 \mathrm{M}$ & 1 & 146 & 158 \\
\hline $15 \%$ & $1 \mathrm{M}$ & 2 & 117 & 133 \\
\hline $15 \%$ & $1 \mathrm{M}$ & 3 & 58 & 58 \\
\hline $15 \%$ & $1,5 \mathrm{M}$ & 1 & 134 & 144 \\
\hline $15 \%$ & $1,5 \mathrm{M}$ & 2 & 120 & 133 \\
\hline $15 \%$ & $1,5 \mathrm{M}$ & 3 & 136 & 149 \\
\hline $15 \%$ & $2 \mathrm{M}$ & 1 & 126 & 136 \\
\hline $15 \%$ & $2 \mathrm{M}$ & 2 & 123 & 135 \\
\hline $15 \%$ & $2 \mathrm{M}$ & 3 & 84 & 86 \\
\hline
\end{tabular}

\section{References}

Bilgen, M. (2006). Wrinkle recovery for cellulosic fabric by means of ionic crosslinking. Polymer Science, 100, 10931102.

Hashem, M., Refaie, R., \& Hebeish, A. (2005). Crosslinking of partially carboxymethylated cotton fabric via cationization. Journal of Cleaner Production, 13(9), 947-954.

Şahin, U. K., Gürsoy, N. Ç., Hauser, P., \& Smith, B. (2011). Yüksek karboksimetilasyon seviyesine ulaşmak için pamuklu kumaşlara uygulanan işlemlerin kıyaslanması . ITÜ Dergisi/d, 10(2). 